\title{
Orta Karadeniz Ekolojik Koşullarında Şeker Mısırda (Zea mays saccharata Sturt.) Değişik Ekim Sıklıkları ve Azot Dozlarının Verim Öğelerine Etkisi
}

\author{
*Erkan ÖZATA ${ }^{\text {Hasan Hüseyin GEÇiT² }}$ Saime ÜNVER IKINCIKARAKAYA² \\ ${ }^{1} 1$ Karadeniz Tarımsal Araştırma Enstitüsü, Samsun \\ ${ }^{2}$ Ankara Üniversitesi, Ziraat Fakültesi, Tarla Bitkileri Bölümü, Ankara \\ *Sorumlu yazar e-posta (Corresponding author; e-mail): erkan_ozata@yahoo.com
}

Öz

Bu çalışma; Orta Karadeniz koşullarında iki yıl süre ile (2010 ve 2012) Merit $F_{1}$ şeker mısır çeşidine altı değişik ekim sıklığı $(50 \times 15,50 \times 20,50 \times 25,70 \times 10,70 \times 15,70 \times 20 \mathrm{~cm})$ ve beş değişik azot dozu $\left(\mathrm{N}_{5}, \mathrm{~N}_{10}, \mathrm{~N}_{15}\right.$ $\mathrm{N}_{20}, \mathrm{~N}_{25} \mathrm{~kg} / \mathrm{da}$ ) uygulanarak, ekim sıklığı ve azot dozlarının verim öğelerindeki değişimin incelenmesi amacıyla yürütülmüştür. Deneme tesadüf bloklarında bölünmüş parseller deneme desenine göre, 4 tekerrürlü olarak kurulmuştur. Ekim sıklıkları ve azot dozları arasında, bitki boyu, ilk koçan yüksekliği ve hasıl verim bakımından istatistiki olarak önemli fark saptanmıştır. Araştırmadan elde edilen sonuçlara göre; $\mathrm{m}^{2}$ de bitki sayısı (ekim sıklıkları) ve azot dozları arttıkça bitki boyu, ilk koçan yüksekliği ve hasıl verim artmıştır. En yüksek; bitki boyu ilk, koçan yüksekliği ve hasıl verim 70x10 (14 bitki/m²) ekim sıkığından, azot dozları bakımından ise yüksek $\mathrm{N}_{25}$ azot dozundan elde edilmiştir.

Anahtar Kelimeler: Şeker mısır, azot dozları, ekim sıklıkları, bitki ve koçan boyu, hasıl verim

\section{Effect of Different Plant Densities on the Agricultural Properties of Sweet Corn (Zea mays saccharata Sturt.) under Middle Blacksea Ecological Conditions}

\section{Abstract}

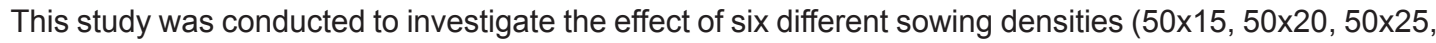
$70 \times 10,70 \times 15,70 \times 20 \mathrm{~cm})$ and five different nitrogen doses $\left(\mathrm{N}_{5}, \mathrm{~N}_{10}, \mathrm{~N}_{15}, \mathrm{~N}_{20}, \mathrm{~N}_{25} \mathrm{~kg} / \mathrm{da}\right)$ sowing densities and nitrogen doses agrıcultural proporties of sweet corn onder Middle Blacksea ecological conditions. The experiment was conducted in 4 replicates according to a split-plot design. The difference between sowing densities and nitrogen doses plant height, ear height and gren yield significant. According to the results, when sowing densities an d nitrogen doses the highest plant height, ear height and green yield was obtained $70 \times 10$ (14 bitki/m²) sowind densitie and dose of nitrogen $\mathrm{N}_{25}$.

Keywords: Sweet corn, sowing density, nitrogen dose, plant height,ear height and gren yield

\section{Giriş}

D ünyada üretilen tane mısırın \%27'si insan beslenmesinde, \%73'ü ise hayvan yemi olarak kullanılmaktadır. Gelişmekte olan ülkelerde tane mısırın kullanımı \%46'sı hayvan beslenmesinde, \%54'ü insan beslenmesi ile sanayi hammaddesi olarak tüketilmektedir. Gelişmiş ülkelerde ise bu oran hayvan beslenmesinde $\% 90$, insan beslenmesi ve sanayi hammaddesi olarak \%10'dur (Anonymous 2010). Dünyada insan beslenmesinde tüketilen günlük kalorinin $\% 11$ 'i tane mısırdan sağlanmaktadır (Kırtok, 1998). Mısır bitkisinin her parçası ayrı bir ekonomik değere sahip olup, doğrudan veya dolaylı olarak üretimine katıldığı 4.000 civarında farklı ürün mevcuttur. Mısırın başlıca kullanım alanları; taze olarak tüketim (haşlama ve közleme), konserve, mısır unu, nişasta, cips, çerez, daneleri ve yeşil aksamı hayvan yemi olarak, yağ, tatlandırıcı, şekerleme, çiklet, çikolata ürünleri, bebek mamaları, salata sosları, alkol, yüksek früktozlu mısır şurubu, diş macunu, etanol (benzine katkı maddesi olarak) üretiminde ve otomotiv sanayi, temizlik malzemeleri, tekstil ve kozmetik sanayi olarak sayılabilir (Özcan 2009). 

saccharata Sturt.) under Middle Blacksea Ecological Conditions"

Şeker mısırı insan beslenmesinde en çok taze olarak tüketilerek kullanılmaktadır. Süt olum dönemi sonunda hasat edildiğinde diğer mısır çeşit gruplarından daha fazla şeker oranına (\%4-12) sahip olan şeker mısırı, gerek besin içeriği gerekse taze konserve ve dondurulmuş şekillerde insan beslenmesinde kullanılmaktadır. Dünya şeker mısır üretimi 9.182.177 ton olup, üretimde ilk üç sırayı 3.888.000 ton ile ABD (\%42.3), 610.000 ton ile Meksika (\%6.6), 577.000 ton ile Nijerya (\%6.3) almaktadır (Anonymous 2008). Türkiye'nin şeker mısır ekim alanı ve üretimi ile ilgili yeterli istatistiki veri bulunmamaktadır. Bununla birlikte istatistiklere geçmemesine karşın özellikle artan şeker mısır talebiyle Çukurova, Ege ve Marmara bölgesinde ekim alanlarında yıldan yıla artışlar olmaktadır. Ülkemizde haşlama ve közleme amacıyla tüketiciye başta sert mısır olmak üzere diğer mısır gruplarına (atdişi ve sert mısır) ait koçanlar sunulduğu göz önüne alındığında, şeker mısırının ülkemizde üretim potansiyelinin yüksek olduğu söylenebilir.

Ekim zamanı, gübre dozu, ekim şekli gibi çok sayıda yetiştirme tekniğinden biri olan ekim sıklığı, özellikle bitki başına düşen yaşam alanının daraltıması veya artırılması yönünden tane verimini etkileyen önemli faktörlerden birisidir.

Bu çalışmada; Orta Karadeniz ekolojik koşullarında Merit $F_{1}$ şeker mısır çeşidine altı

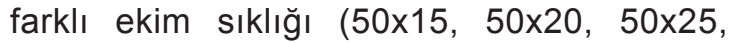
$70 \times 10,70 \times 15,70 \times 20 \mathrm{~cm}$ ) ve beş değişik azot dozu $\left(\mathrm{N}_{5}, \quad \mathrm{~N}_{10}, \quad \mathrm{~N}_{15}, \quad \mathrm{~N}_{20}, \quad \mathrm{~N}_{25} \mathrm{~kg} / \mathrm{da}\right)$ uygulanarak, ekim sıklıkları ve azot dozlarının verim öğeleri üzerindeki değişime etkisi araştırılmıştır.

\section{Materyal ve Yöntem}

Araştırma Gıda, Tarım ve Hayvancılık Bakanlığı, Tarımsal Araştırmalar ve Politikalar
Genel Müdürlüğü'ne bağlı Karadeniz Tarımsal Araştırma Enstitüsünün, Çarşamba Deneme İstasyonunda yürütülmüştür

kim öncesi deneme alanlarından alınan toprak örnekleri, Toprak Analiz Laboratuarlarında analiz edilmiştir. Deneme yeri toprağı hafif alkali reaksiyonda, killi-tınlı tekstüre sahiptir. Alınabilir fosfor içeriği bakımından fakir, organik maddesi yetersiz ve potasyum fazla miktardadır. Tuz içeriği yok denecek kadar az olup, çalışmanın yapıldığı tarla kireçli bir yapıya sahiptir. Toprağın toplam azot içeriği birinci yıl $2.45 \mathrm{~kg} / \mathrm{da}$, ikinci yıl ise $2.92 \mathrm{~kg} / \mathrm{da}$ olarak belirlenmiştir.

Denemenin yürütüldüğü yıllardaki yağış değerleri uzun yıllar (1974-2012) yağış ortalamaları ile karşılaştırıldığında aylık bazda önemli farklılıklar görülmektedir (Çizelge 1). Denemenin ilk yılı yetiştirme periyodu (bitkinin tarlada olduğu aylar) yağış toplamı $(222.9 \mathrm{~mm})$ uzun yıllar $(225.9 \mathrm{~mm})$ yağış toplamı ile benzerlik göstermesine karşın, ikinci yıldaki yetiştirme periyodu yağış toplamı (344.2 mm) hem denemenin ilk yılında hem de uzun yıllar ortalamasına oranla oldukça fazladır.

Denemenin her iki yılda ekildiği Mayıs ayı ortalama yağış miktarı uzun yıllar yağış miktarının oldukça altında seyretmiştir. Haziran ayında denemenin ilk yılında yağış miktarı uzun yıllar yağış miktarının iki katından daha fazla olarak ortaya çıkmışken, denemenin ikinci yılında uzun yıllar yağış miktarının yaklaşık yarısı kadar yağış alınmıştır. Temmuz ayı yağış miktarı; denemenin ilk yılında uzun yıllar yağış ortalamasının altında seyretmiş, ikinci yılda ise uzun yıllar ortalamasının üç katı yağış alınmıştır. Deneme hasatlarının yapıldığı Ağustos ayı yağış miktarı; birinci yılda uzun yılların yaklaşık 1/4'ü kadar yağış alınmışken, denemenin ikinci yılında uzun yıllar ortalamasının yaklaşık beş katı yağış alınmıştır.

Çizelge 1. Deneme yerinin topraklarının bazı özellikleri Table 1. Soil properties of trial area

\begin{tabular}{lccc}
\hline \multicolumn{1}{c}{ Deneme Yeri } & $\begin{array}{c}\text { Tahlil değerleri } \\
(2010)\end{array}$ & $\begin{array}{c}\text { Tahlil değerleri } \\
(2012)\end{array}$ & $\begin{array}{c}\text { Samsun- } \\
\text { Çarşamba }\end{array}$ \\
\hline Bünye & 66.0 & 68.0 & Killi-Tınlı \\
$\mathrm{pH}$ & 7.86 & 7.82 & Hafif Alkali \\
$\mathrm{P}_{2} \mathrm{O}_{5}(\mathrm{~kg} / \mathrm{da})$ & 2.52 & 2.6 & Çok az \\
$\mathrm{K}_{2} \mathrm{O}(\mathrm{kg} / \mathrm{da})$ & 94.0 & 92.0 & Fazla \\
Organik Madde $(\%)$ & 1.76 & 1.74 & Az \\
Kireç CaCO & $(\%)$ & 9.23 & Orta kireçli \\
$\%$ Total tuz & 0.054 & 0.066 & Tuzsuz \\
Toplam Azot $(\mathrm{kg} / \mathrm{da})(0-30 \mathrm{~cm})$ & 2.45 & 2.92 & \\
\hline
\end{tabular}


Çizelge 2. Deneme alanının 2010-2012 yılları ve uzun yıllara (1974-2012) ait bazı iklim verileri (Samsun Bölge Meteoroloji İstasyonu)

Table 2. Climate data of trial area between 2010 - 2012 and long term (1974-2012)(Samsun Regional Meteorological Station)

\begin{tabular}{|c|c|c|c|c|c|c|c|c|c|}
\hline \multirow[t]{3}{*}{ AYLAR } & \multicolumn{3}{|c|}{ Yağış Toplamı (mm) } & \multicolumn{3}{|c|}{ Ortalama Sıcaklık $\left({ }^{\circ} \mathrm{C}\right)$} & \multicolumn{3}{|c|}{ Nispi Nem (\%) } \\
\hline & & & Uzun & & & Uzun & & & Uzun \\
\hline & 2010 & 2012 & Yillar & 2010 & 2012 & Yıllar & 2010 & 2012 & Yillar \\
\hline Nisan & 70.0 & 10.4 & 58.3 & 11.6 & 13.3 & 11.1 & 83.6 & 74.4 & 79.5 \\
\hline Mayıs & 16.0 & 34.4 & 51.1 & 16.9 & 17.5 & 15.4 & 78.8 & 82.3 & 79.4 \\
\hline Haziran & 109.5 & 24.4 & 48.0 & 21.9 & 21.9 & 20.3 & 82.0 & 76.4 & 77.1 \\
\hline Temmuz & 19.4 & 96.0 & 31.8 & 24.7 & 24.0 & 23.3 & 76.6 & 77.1 & 76.7 \\
\hline Ağustos & 8.0 & 179.6 & 36.7 & 25.9 & 23.0 & 23.5 & 78.0 & 80.0 & 74.6 \\
\hline Ortalama & -- & -- & -- & 20.2 & 19.9 & 18.7 & 79.8 & 78.0 & 77.4 \\
\hline Toplam & 222.9 & 344.2 & 225.9 & & & & & & \\
\hline
\end{tabular}

Sıcaklık bakımından denemenin yürütüldüğü her iki yıl ortalama değerleri birbirine yakın, uzun yıllardan ise farklılık göstermiştir. Denemenin ilk yılı aylık ortalama sıcaklık değerleri uzun yıllar ortalamasına göre (Mayıs-Ağustos) yaklaşık $1^{\circ} \mathrm{C}$ daha yüksek gerçekleşmiştir. Denemenin ilk yılında çiçeklenme ve tane doldurma dönemlerinde (Temmuz ikinci haftası ve Ağustosun ilk haftası arası) ortalama sıcaklık uzun yıllar ortalama sıcaklığından yaklaşık $2^{\circ} \mathrm{C}$ daha yüksek olmuştur. Denemenin ikinci yılı sıcaklık değerleri uzun yıllar sıcaklık değerlerine göre aylık bazda (Ağustos ayı hariç) uzun yıllar ortalamasının üzerinde seyretmiştir. Yıllık ortalama nisbi nem değerlerinin, uzun yıllar ortalaması \%77.4 iken, çalışmanın birinci yııında \%79.8, ikinci yılında \%78.0 olarak gerçekleşmiştir. Aylık nisbi nem değerleri yağış miktarlarına bağlı olarak her iki yılda da farklılıklar göstermiştir.

Denemede Merit $\left(F_{1}\right)$ hibrit şeker mısır çeşidi kullanılmıştır. Araştırma Tesadüf Bloklarında Bölünmüş Parseller Deneme Desenine göre dört tekrarlamalı olarak yürütülmüştür. Ana parsellere 6 farklı ekim sıklığı (50x15, 50x20, $50 \times 25,70 \times 10,70 \times 15$ ve $70 \times 20 \mathrm{~cm})$, alt parsellere ise 5 farklı azot dozu $(5,10,15,20$, $25 \mathrm{~N} \mathrm{~kg} / \mathrm{da}$ ) tesadüfî olarak yerleştirilmiştir. Dekardaki bitki sayısı ekim sıklığına bağlı olarak 7.143-14.285 adet arasında değişmiştir. Denemede alt parseller 6 metre uzunluğunda dört sıradan oluşmuştur. Alt parseller $50 \mathrm{~cm}$ sıra arası alanlarda $\left(2 \times 6=12 \mathrm{~m}^{2}\right) 12 \mathrm{~m}^{2}, 70 \mathrm{~cm}$ sıra arası olanlarda $\left(2.8 \times 6=16.8 \mathrm{~m}^{2}\right) 16.8 \mathrm{~m}^{2}$ ' dir.

Deneme alanında toprak işleme pullukla yapılmış, daha sonra da rotatiller ile tohum yatağı hazırlanmıştır. Ekim plantuarla (sivriç) açılan 4-5 cm derinliğindeki her ocağa elle 2'şer tohum bırakılarak (parselde olması gereken bitki sayısını garanti altına almak için) denemenin ilk yılında 12 Mayıs 2010 tarihinde, ikinci yılında ise
8 Mayıs 2012 tarihinde yapılmıştır. Ekimden bir hafta sonra çıkış olmayan ocaklarda yeniden ekim yapılmıştır.

Toprak analizi sonucunda taban gübresi olarak ekim öncesi (bitkilerin gelişiminde sınırlayıcı bir etki oluşmaması için) saf $8 \mathrm{~kg} / \mathrm{da}$ $\mathrm{P}_{2} \mathrm{O}_{5}$ toprağa verilmiştir. Azot dozları $(\mathrm{N}) 5,10$, $15,20,25 \mathrm{~kg} / \mathrm{da}$ alt parsellere uygulanmıştır. Azot dozuna uygun olarak her alt parsele verilecek gübre miktarı iki eşit parçaya bölünerek tartııp paketlenmiş ve yarısı ekimle birlikte, diğer yarısı ise bitkiler 4-6 yapraklı (V4V6 gelişim evresi) olduğu dönemde banda (bitkilerin tek taraflı 4-5 cm yanına) verilmiştir.

Hasat, her parselde kenarlardan birer sıra, parsel başından ve sonundan $50 \mathrm{~cm}$ 'lik kısım kenar tesiri olarak ayrıldıktan sonra geri kalan bitkilerdeki koçanlar elle bitkiler ise orakla hasat edilmiştir. Hasat zamanının saptanması, direkt olarak kaliteyi etkilediği için en önemli aşama olarak ele alınmıştır. Hasat tane neminin \%7075 olduğu dönemde (koçan püsküllerinin kahverengileştiği dönem) (Olsen ve ark. .1990; Öktem 2008) elle yapılmıştır. Denemenin ilk yılında hasat 2-9 Ağustos 2010 tarihinde ikinci yılında ise 1-10 Ağustos 2012 tarihleri arasında yapılmıştır.

Araştırma sonunda elde edilen veriler MSTAT-C paket programı kullanılarak değerlendirilmiştir. Tesadüf bloklarında bölünmüş parseller deneme desenine göre 4 tekrarlamalı olarak yürütülen denemeden elde edilen veriler yıllar itibarı ile birleştirilerek varyans analizi yapılmış, yıllar arasındaki fark önemli çıktığı için yıllar ayrı ayrı varyans analizine tabii tutulmuştur. Farklııkların önem düzeyleri $\mathrm{F}$ testine göre, farklılık gruplandırması ise ortalama sayısı 5'den az olanlarda LSD, fazla olanlarda ise Duncan testine göre yapılmıştır (Düzgüneş ve ark. 1987). 


\section{Bulgular ve Tartışma}

Şeker mısırında verim ve bazı verim öğelerine ait yıllar üzerinden birleştirilmiş varyans analizleri sonuçları Çizelge 3 'de verilmiştir. Her iki yılda da denemeye alınan genotiplerin analizine göre bitki boyu, ilk koçan yüksekliği ve hasıl verim özellikleri bakımından istatistiki olarak farklılık $(p<0.01)$ önemli bulunmuştur.

İki yıl birlikte değerlendirildiğinde ekim sıklıkları açısından; en yüksek bitki boyu 212.1 $\mathrm{cm}$ ile $70 \times 10\left(14 \mathrm{bitki} / \mathrm{m}^{2}\right)$ ekim sıklı̆ı̆ından, en kısa $193.7 \mathrm{~cm}$ ile 70x20 (7 bitki $\left./ \mathrm{m}^{2}\right)$ ekim sıklığından belirlenmiştir. Azot dozları açısından ise en uzun bitki boyu $211.1 \mathrm{~cm}$ ile $\mathrm{N}_{25}$ azot dozundan belirlenirken, en kısa bitki boyu 192.7 $\mathrm{cm}$ ile $\mathrm{N}_{5}$ dozundan ölçülmüştür (Çizelge 4.4). Ekim sıklıkları arttıkça bitki boyu da artış göstermektedir. Birim alanda bitki sayısının artması bitkiler arasında ışıktan daha fazla faydalanmak için yarışmayı (rekabeti) artırmaktadır. Sık ekimlerde yetersiz ışık veya gölgeleme alt boğumlarda odunlaşmanın gecikmesine neden olmakta, sonuçta da bitki boyu uzamaktadır. Araştırmadan elde edilen sonuçlar; bitki sıklığı arttıkça bitki boyunun arttığını bildiren, Asghari et al. (2006), Kahrıman ve ark. (2007), Suksoon et al. (2007), Bhatt et al. (2011)'nin bulguları ile benzerlik göstermektedir. Uygulanan azot dozlarının artısıyla beraber mısır bitkisinin daha fazla azotlu gübre almasına bağlı olarak vejatatif aksam gelişmekte (boğum araları uzamakta) bitki boyları artış göstermektedir. Araştırma da elde ettiğimiz sonuçlar; Turgut (2000), Kara (2006), El-Yazied et al. (2007), Özkan (2007), Bhatt (2012) azot dozları arttıkça bitki boyunun arttığını bildiren araştırıcıların sonuçları ile uyum gösterirken, artan azot dozlarının bitki boyuna etkili etmediğini bildiren Sadeghi and Bahrani (2002)'nin bulguları ile uyum göstermemektedir.

Ekim sıklıkları incelendiğinde; iki yıl birlikte değerlendirildiğinde en yüksek ilk koçan yüksekliği $91.5 \mathrm{~cm}$ ile $70 \times 10\left(14 \mathrm{bitki} / \mathrm{m}^{2}\right)$ ekim sıklığından, en kısa $79.4 \mathrm{~cm}$ ile $70 \times 20$ $\left(7 \mathrm{bitki} / \mathrm{m}^{2}\right)$ ekim sıklığından belirlenmiştir. Azot dozları açısından incelendiğinde en uzun ilk koçan yüksekliği $89.6 \mathrm{~cm}$ ile $\mathrm{N}_{25}$ ile azot

Çizelge 3. Şeker mısırında farklı ekim sıklığı ve azot dozları özelliklere ait varyans analiz sonuçları Table 3. Variance analysis results of different sowing densities and nitrogen dose parameters of sweet corn

\begin{tabular}{lcccccc}
\hline Özellikler & Yıl & $\begin{array}{c}\text { Ekim } \\
\text { Sıklığı }\end{array}$ & $\begin{array}{c}\text { Azot } \\
\text { Dozları }\end{array}$ & $\begin{array}{c}\text { E. S. X } \\
\text { A. D. }\end{array}$ & $\begin{array}{c}\text { YXE.S.X A. } \\
\text { D. }\end{array}$ & VK \\
\hline Bitki boyu & $* *$ & $* *$ & $* *$ & Ö.D. & Ö.D. & 3.09 \\
Ilk koçan yüksekliği & $* *$ & $* *$ & $* *$ & $* *$ & $*$ & 5.92 \\
Hasıl verim & $* *$ & $* *$ & $* *$ & Ö.D. & Ö.D. & 4.83 \\
SD & 1 & 5 & 4 & 20 & 20 & \\
\hline
\end{tabular}

Çizelge 4. Şeker mısırda farklı ekim sıklığı ve azot dozlarından elde edilen bitki boyu ortalamalarının farklııı gruplandırmaları (cm) (2010-2012)

Table 4. Sweet corn plant height $(\mathrm{cm})$ averages for different sowing densities and nitrogen doses with relative Duncan groups (2010-2012)

\begin{tabular}{|c|c|c|c|c|c|c|c|c|}
\hline \multicolumn{5}{|c|}{2010} & \multicolumn{4}{|c|}{2012} \\
\hline $\begin{array}{l}\text { Ekim. } \\
\text { Sık. }\end{array}$ & \multicolumn{2}{|c|}{$\begin{array}{c}\text { Ort. ve Duncan } \\
\text { Grup. }\end{array}$} & Azot Doz. & $\begin{array}{c}\text { Ort. ve } \\
\text { Duncan } \\
\text { Grup. }\end{array}$ & \multirow{2}{*}{$\begin{array}{c}\text { Ekim. } \\
\text { Sık. } \\
70 \times 10\end{array}$} & \multirow{2}{*}{$\begin{array}{c}\text { Ort. ve } \\
\text { Duncan } \\
\text { Grup. } \\
192.2\end{array}$} & $\begin{array}{l}\text { Azot } \\
\text { Doz. }\end{array}$ & $\begin{array}{c}\text { Ort. ve } \\
\text { Duncan Grup. }\end{array}$ \\
\hline $70 \times 10$ & 232.0 & a & $\mathrm{N}_{25}$ & $234.5 \quad a$ & & & $\mathrm{~N}_{25}$ & 187.6 \\
\hline $50 \times 15$ & 228.4 & $a b$ & $\mathrm{~N}_{20}$ & $231.9 a b$ & $50 \times 15$ & 191.9 & $\mathrm{~N}_{20}$ & $186.5 \mathrm{ab}$ \\
\hline $70 \times 15$ & 225.9 & $a b$ & $\mathrm{~N}_{15}$ & $226.8 \quad b$ & $70 \times 15$ & 182.2 & $\mathrm{~N}_{15}$ & $184.1 \mathrm{bc}$ \\
\hline $50 \times 20$ & 221.6 & bc & $\mathrm{N}_{10}$ & 219.4 & $50 \times 20$ & 181.8 & $\mathrm{~N}_{10}$ & $180.8 \quad c$ \\
\hline $50 \times 25$ & 221.4 & $\mathrm{bc}$ & $\mathrm{N}_{5}$ & 211.1 & $50 \times 25$ & 179.7 & $\mathrm{~N}_{5}$ & 174.3 \\
\hline $70 \times 20$ & 219.2 & $\mathrm{C}$ & \multicolumn{2}{|c|}{ Y. Ort: 224.8} & $70 \times 20$ & 168.1 & & Y. Ort: 182.6 \\
\hline \multicolumn{9}{|c|}{$2010-2012$} \\
\hline & & \multicolumn{2}{|c|}{ Ekim Sık. } & Ortalama & Azot Doz. & \multicolumn{2}{|r|}{ Ortalama } & \\
\hline & & \multicolumn{2}{|c|}{$70 \times 10(14$ bitki/m²) } & 212.1 & $\mathrm{~N}_{25}$ & \multicolumn{2}{|r|}{211.1} & \\
\hline & & \multicolumn{2}{|c|}{$50 \times 15\left(13 \mathrm{bitki} / \mathrm{m}^{2}\right)$} & 210.2 & $\mathrm{~N}_{20}$ & \multicolumn{2}{|r|}{209.2} & \\
\hline & & \multicolumn{2}{|c|}{$70 \times 15(10$ bitki/m²) } & 204.1 & $\mathrm{~N}_{15}$ & \multicolumn{2}{|r|}{205.5} & \\
\hline & & \multicolumn{2}{|c|}{$50 \times 20\left(10 \mathrm{bitki} / \mathrm{m}^{2}\right)$} & 201.7 & $\mathrm{~N}_{10}$ & \multicolumn{2}{|r|}{200.1} & \\
\hline & & \multirow{2}{*}{\multicolumn{2}{|c|}{$\begin{array}{l}50 \times 25\left(8 \text { bitki } / \mathrm{m}^{2}\right) \\
70 \times 20\left(7 \text { bitki } / \mathrm{m}^{2}\right)\end{array}$}} & \multirow{2}{*}{$\begin{array}{l}200.6 \\
193.7\end{array}$} & $\mathrm{~N}_{5}$ & \multirow{2}{*}{\multicolumn{2}{|c|}{192.7}} & \\
\hline & & & & & & & & \\
\hline
\end{tabular}


Çizelge 5. Şeker mısırda farklı ekim sıklığı ve azot dozlarından elde edilen ilk koçan yüksekliği ortalamalarının (cm) farklılık gruplandırmaları (2010-2012)

Table 5. Sweet corn ear height $(\mathrm{cm})$ averages for different sowing densities and nitrogen doses with relative Duncan groups (2010-2012)

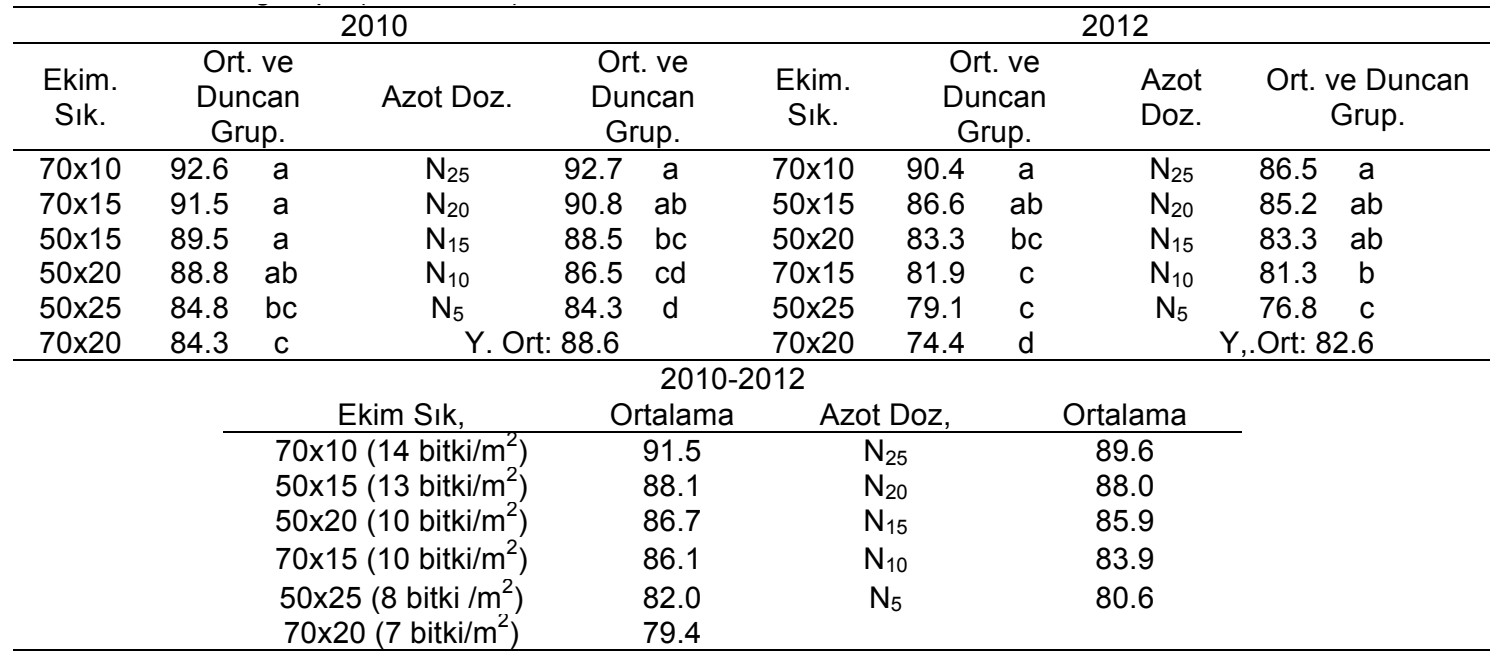

dozundan belirlenirken, en kısa ilk koçan yüksekliği 80.6 cm ile N5 dozundan ölçülmüştür (Çizelge 4). İlk koçan yüksekliği çeşitlerin genetik yapılarına bağlı olarak değişmektedir. Ayrıca bitki boyunun çevre koşullarından etkilenmesinin bir sonucu olarak ilk koçan yükseklikleri de değişim gösterebilmektedir. Bitki boyuna benzer olarak ilk koçan yükseklikleri de ekim sıklıklarından önemli derecede etkilenmektedir. Ekim sıklığı arttıkça bitkiler için gerekli ışığın temini için bitki boyunun gerekli ışığın temini için uzaması şeklinde olup, bu da ilk koçan yüksekliği artışına neden olmaktadır.

Elde ettiğimiz sonuçlar; Kahrıman ve ark. (2007)'nin ilk koçan yüksekliğinin ekim sıklıkları arttıkça arttığını belirten sonuçlarıyla uyum içersindedir. Ancak Alıcı (2005) ve Şirikçi (2006)'nin bitki sıklığı arttıkça ilk koçan yüksekliğinin azaldığını bildirdiği bulgularıyla ise farklılık göstermektedir. Azot dozları arttıkça bitki boyuna benzer olarak ilk koçan yükseklikleri de artmaktadır. Bu artış, azotlu gübrelerin vejetatif gelişmeyi teşvik etmesinden kaynaklanmaktadır (Kün 1985). Azot dozları arttıkça ilk koçan yüksekliğinin arttığını tespit ettiğimiz sonuçlarımız Turgut (2000), Kara (2006) ve Özkan (2007)'ın bulgularıyla örtüşmektedir. İki yıl birlikte değerlendirildiğinde en yüksek hasıl verim $2559 \mathrm{~kg} / \mathrm{da}$ ile 70x10 (14 bitki/m²) ekim sıklığından, en düşük hasıl verim $2251 \mathrm{~kg} / \mathrm{da}$ ile $70 \times 20 \quad\left(7 \quad\right.$ bitki $\left./ \mathrm{m}^{2}\right)$ ekim sıklığından belirlenmiştir. Azot dozları bakımından ise en yüksek hasıl verim $2628 \mathrm{~kg} / \mathrm{da}$ ile $\mathrm{N}_{25}$ ile azot dozundan belirlenirken, en düşük hasıl verim $2210 \mathrm{~kg} / \mathrm{da}$ ile $\mathrm{N}_{5}$ dozundan ölçülmüştür (Çizelge 6).

Bitki sıklıkları artıkça hasıl verim artmaktadır. Birim alanda bitki sayısının artması ile bitkiler arasında ışıktan yararlanmak için rekabette artmaktadır. Işıklanmanın yetersiz olduğu durumlarda bitkilerde ışık bulabilmek için boylarını arttırmaktadır. En yüksek ekim sıklığından en yüksek hasıl verimin alınmasının; ekim sıklığının artmasına paralel olarak vejatatif aksamında (sap+yaprak) artış göstermesinden kaynaklandığı düşünülmektedir. Araştırma sonucunda elde ettiğimiz bulgular; bitki sıklıkları arttıkça hasıl verimin arttığını belirten, Kar ve ark. (2006), Mohammadi and Alıkhanı (2007), Mohammadi et al. (2008) ve Bhatt et al. (2011) araştırıcıların bulguları ile örtüşmektedir.

Azot dozlarının hasıl verim üzerine etkisi istatiksel olarak önemli bulunmuştur. Artan azot dozları ile hasıl verimde artış göstermektedir. Uygulanan azot dozlarının artısıyla beraber mısır bitkisinin daha fazla azotlu gübre almasına bağlı olarak vejatatif aksam gelişmekte (boğum araları uzamakta) hasıl verimde artış göstermektedir. Araştırma sonuçları; Asghari et al. (2006), Bhatt et al. (2011)'nin azot dozları arttıkça hasıl veriminde arttığını belirttikleri sonuçları ile uyum içersindedir. 

saccharata Sturt.) under Middle Blacksea Ecological Conditions"

Çizelge 6. Şeker mısırda farklı ekim sıklığı ve azot dozlarından elde edilen hasıl verim ortalamalarının farklıık gruplandırmaları (kg/da) (2010-2012)

Table 6. Sweet corn gren yield ( $\mathrm{kg} / \mathrm{da}$ ) averages for different sowing densities and nitrogen doses with relative Duncan groups (2010-2012)

\begin{tabular}{|c|c|c|c|c|c|c|c|c|c|c|c|}
\hline \multicolumn{6}{|c|}{2010} & \multicolumn{6}{|c|}{2012} \\
\hline Ekim Sık. & \multicolumn{2}{|c|}{$\begin{array}{l}\text { Ort. ve Duncan } \\
\text { Grup. }\end{array}$} & \multirow{2}{*}{$\begin{array}{c}\begin{array}{c}\text { Azot } \\
\text { Doz. }\end{array} \\
\mathrm{N}_{25}\end{array}$} & \multicolumn{2}{|c|}{$\begin{array}{c}\text { Ort. ve Duncan } \\
\text { Grup. }\end{array}$} & \multirow{2}{*}{$\begin{array}{l}\text { Ekim. } \\
\text { Sık. }\end{array}$} & \multicolumn{2}{|l|}{$\begin{array}{l}\text { Ort. ve } \\
\text { Duncan } \\
\text { Grup. }\end{array}$} & $\begin{array}{l}\text { Azot } \\
\text { Doz. }\end{array}$ & \multicolumn{2}{|c|}{$\begin{array}{l}\text { Ort. ve Duncan } \\
\text { Grup. }\end{array}$} \\
\hline $70 \times 10$ & 2951 & $a$ & & 2992 & $a$ & & 2188 & $a$ & $\mathrm{~N}_{25}$ & 2264 & \\
\hline $50 \times 15$ & 2950 & a & $\mathrm{N}_{20}$ & 2929 & $a$ & $50 \times 25$ & 2187 & a & $\mathrm{N}_{20}$ & 2211 & $a$ \\
\hline $50 \times 20$ & 2909 & a & $\mathrm{N}_{15}$ & 2918 & $b$ & $70 \times 10$ & 2167 & a & $\mathrm{N}_{15}$ & 2100 & $\mathrm{~b}$ \\
\hline $70 \times 15$ & 2838 & $b$ & $\mathrm{~N}_{10}$ & 2707 & C & $50 \times 15$ & 2093 & a & $\mathrm{N}_{10}$ & 2023 & $b$ \\
\hline $70 \times 20$ & 2591 & $b$ & $\mathrm{~N}_{5}$ & 2608 & c & $70 \times 15$ & 1950 & & $\mathrm{~N}$ & 18 & \\
\hline \multirow[t]{9}{*}{$50 \times 25$} & 2536 & $b$ & \multicolumn{3}{|c|}{ Y. Ort: 2831} & $70 \times 20$ & 1904 & & & \multicolumn{2}{|c|}{ Y. Ort: 2082} \\
\hline & & & & & & $2010-20$ & & & & & \\
\hline & & & \multicolumn{3}{|c|}{ Ekim Sık. } & Ortalama & \multicolumn{2}{|c|}{$\begin{array}{l}\text { Azot } \\
\text { Doz. }\end{array}$} & \multicolumn{3}{|c|}{ Ortalama } \\
\hline & & & \multirow{6}{*}{\multicolumn{2}{|c|}{$\begin{array}{l}70 \times 10\left(14 \mathrm{bitki} / \mathrm{m}^{2}\right) \\
50 \times 20\left(10 \mathrm{bitki} / \mathrm{m}^{2}\right) \\
50 \times 15\left(13 \mathrm{bitki} / \mathrm{m}^{2}\right) \\
70 \times 15\left(10 \mathrm{bitki} / \mathrm{m}^{2}\right) \\
50 \times 25\left(8 \mathrm{bitki} / \mathrm{m}^{2}\right) \\
70 \times 20\left(7 \mathrm{bitki} / \mathrm{m}^{2}\right)\end{array}$}} & & 2559 & \multirow{6}{*}{\multicolumn{2}{|c|}{$\begin{array}{l}N_{25} \\
N_{20} \\
N_{15} \\
N_{10} \\
N_{5}\end{array}$}} & \multicolumn{3}{|c|}{2628} \\
\hline & & & & & & 2549 & & & \multicolumn{3}{|c|}{2570} \\
\hline & & & & & & 2522 & & & \multicolumn{3}{|c|}{2509} \\
\hline & & & & & & 2394 & & & \multirow{2}{*}{\multicolumn{3}{|c|}{2365}} \\
\hline & & & & & & 2362 & & & \\
\hline & & & & & & 2251 & & & & & \\
\hline
\end{tabular}

\section{Sonuç}

Yapılan çalışma sonucunda; Bitkilerde sıklık arttıkça ışıklanma rekabetinden dolayı ilk koçan yüksekliği ve bitki boyu artmıştır. En yüksek ilk koçan yüksekliği ve bitki boyu $70 \times 10$ (14 bitki/m²) ekim sıklığından, en düşük ortalama 70x20 (7 bitki/m²) elde edilmiştir. Birim alanda bitki sayısının artması elde edilen hasıl veriminin de artmasına neden olmuştur. Azot dozları açısından en yüksek ortalamalar N25 azot dozu, en düşük ortalamalar N5 azot dozundan belirlenmiş olup, ekim sıklıkları ve azot dozlarının artması bitki boyu ile ilk koçan yüksekliğinde lineer bir artış sağlamıştır.

\section{Kaynaklar}

Akbar H.M. and Muhammad T.J., 2002. Yield Potential of Sweet Corn as Influenced by Different Levels of Nitrogen and Plant Population. Asian Journal of Plant Sci., No: 631-633

Anonymous, 2008b. Tab100.xls. World Swt Corn (Gm Maize): Production by Country, 1961-2007 http://usda.mannlib.cornell.edu/usda/ers/Swe etCorn/ TABLE98.xls Erişim tarihi: 10.01.2013

Anonymous, 2010. FAO Statistical Databases. Erişim tarihi: 10.01.2013.10:15 http://faostat.fao.org/ site/535/default.aspx\#ancor

Asghari J., Zareei B. and Barzegari M., 2006. Effect of Plant Density and Planting Pattern on Growth Parameters and Yield of Two Promising Corn Hybrids (Zea mays L.). Agricultural Sciences and Technology; 20 (2), Mashhad: Ferdowsi University of Mashhad, Pe123-Pe133
Bhatt S., Yakadri M., Sivalashmi Y. and Vilaykumar B., 2011. Production Potencial of Sweet Corn (Zea mays) as Influenced by Varying Plant Densities and Nitrogen Levels. ASA, CSSA, SSSA International Annual Meetings October 16-19, 2011

Düzgüneş O., Kesici T., Kavuncu O. and Morrone F. 1987. Araştırma ve Deneme Metotları (İstatistik Metotları II). Ankara Üniv. Ziraat Fak. Yay. No: 1021, 381 s., Ankara

El-Yazied A.A., Ragab M.E., Rawia E.I. and El-Wafa S.M.A., 2007. Effect of nitrogen fertigation levels and chelated calcium foliar application on the productivity of sweet corn. Arab Univ. Journal of Agricultural Sciences, 15(1): 131139

Kahrıman F, Egesel C, Turhan H, Özkan P, 2007. Şeker Mısırda (Zea mays saccharata Sturt.) Farklı Tohumluk Miktarlarının Koçan Verimi Üzerine Etkisi. Türkiye VII. Tarla Bitkileri Kongresi, 25-27 Haziran 2007, Erzurum. Cilt1: 318-321

Kar P.P., Bark K.C., Makapatra P.K., Garnayak L.M., Rath B.S., Bastia D.K. and Khanda C.M., 2006. Effect of planting geometry and nitrogen on yield, economics and nitrogen uptake of sweet corn (Zea mays). Indian Journal of Agronomy 51(1): 43-45

Kara B., 2006. Çukurova Koşullarında Değişik Bitki Sıklıkları ve Farklı Azot Dozlarında Mısırın Verim ve Verim Özellikleri ile Azot Alım ve Kullanım Etkinliğinin Belirlenmesi (Doktora Tezi). Çukurova Üniversitesi Fen Bilimleri Enstitüsü, $162 \mathrm{~s}$. Adana

Kün E., 1985., Sıcak İklim Tahılları. Ankara Üniv. Zir. 
Fak. Yay. No: 953, Ders Kitabı No: 275, Ankara. $317 \mathrm{~s}$

Mohammadi K. H., Aghaalıkhanı M., Modarros and Sanavy S.A.M., 2008. Effect of plant density and sowing date on economic yield and sugar content of sweet corn. Iranian Journal of Field Crop Science, 40(1): 27-35

Olsen J.K., Blight G.W. and Gillespie D., 1990. Comparison of yield, cob characteristics and sensory quality of six super sweet (Sh2) corn cultivars grown in a subtropical environment. Austrilian Journal of Experimental Agriculture. 30, 387-393

Öktem A., 2008. Determination of selection criterions for sweet corn using path coefficient analyses. Cereal Research Communications 36(4) Budapest: Akadémiai Kiadó, 561-570

Özkan A., 2007. Çukurova Koşullarında Değişik Azot Dozu Uygulamalarının İki Cin Mısırı (Zea mays everta Sturt.) Çeşidinde Tane Verimi, Tarımsal Özellikler ve Bazı Kalite Özelliklerine Etkisi (Doktora Tezi). Çukurova Üniversitesi Fen Bilimleri Enstitüsü, $125 \mathrm{~s}$. Adana
Sadeghi H. and Bahrani M.J., 2002. Effects of plant density and nitrogen rates on morphological characteristics and kernel protein contents of corn (Zea mays L.). Iranian Journal of Agricultural Sciences, 33(3): 403-412

SukSoon L., Yang S.K. and Hong S.B., 2007. Optimum plant populations of a super sweetcorn hybrid at different planting dates. Korean Journal of Crop Science, 52(3): 334340

Şirikci M., 2006. Kahramanmaraş Koşullarında Üç Mısır Çeşidinde Farklı Bitki Sıklığının Verim ve Bazı Özelliklere Etkisi. Çukurova Üni., Fen Bilimleri Enst., Tarla Bitkileri Anabilim Dalı, Adana, $116 \mathrm{~s}$

Turgut İ., 2000. Bursa koşullarında yetiştirilen şeker mısırında (Zea mays saccharata Sturt.) bitki sıklığının ve azot dozlarının taze koçan verimi ile verim öğeleri üzerine etkisi. Turk J. Agric. For., 24: 341-347 